\title{
Inhibition of Nuclear Factor- $\kappa B$ Ameliorates Bowel Injury and Prolongs Survival in a Neonatal Rat Model of Necrotizing Enterocolitis
}

\author{
ISABELLE G. DE PLAEN, SHIRLEY X. L. LIU, RUNLAN TIAN, ISAAC NEEQUAYE, MICHAEL J. MAY, XIN-BING HAN,
} WEI HSUEH, TAMAS JILLING, JING LU, AND MICHAEL S. CAPLAN

\begin{abstract}
Department of Pediatrics [I.G.P., S.X.L.L., R.T., I.N., X.-B.H.], Department of Pathology [W.H.], Children's Memorial Hospital, Northwestern University Medical School, Chicago, Illinois 60614; Department of Animal Biology [M.J.M.], School of Veterinary Medicine, University of Pennsylvania, Philadelphia, Pennsylvania 19104; Department of Pediatrics [T.J., J.L., M.S.C.], Evanston Northwestern Healthcare Research Institute, Evanston, Illinois 60201
\end{abstract}

\begin{abstract}
Necrotizing enterocolitis (NEC) is a major cause of morbidity and death in premature infants. NEC is associated with increased levels of pro-inflammatory cytokines in plasma and tissues that are regulated by the transcription factor nuclear factor $-\kappa \mathrm{B}(\mathrm{NF}-\kappa \mathrm{B})$. It remains unknown, however, whether NF- $\kappa \mathrm{B}$ mediates injury in neonatal NEC. We therefore examined the activation status of NF- $\kappa \mathrm{B}$ perinatally in the small intestine and in a neonatal rat model of NEC. We found that intestinal NF- $\kappa \mathrm{B}$ is strongly activated at birth and, in dam-fed newborn rats, is down-regulated within a day. In contrast, $\mathrm{NF}-\kappa \mathrm{B}$ remains strongly activated at both $\mathrm{d} 1$ and $\mathrm{d} 2$ in stressed animals, and this is accompanied by a significant decrease in the levels of the endogenous NF- $\kappa \mathrm{B}$ inhibitor protein $\mathrm{I} \kappa \mathrm{B} \alpha$ and $\mathrm{I} \kappa \mathrm{B} \beta$ at d 2. To determine the importance of elevated NF- $\kappa$ B activity in intestinal injury in NEC, we administered the NEMO-binding domain (NBD) peptide that selectively inhibits the critical upstream $\mathrm{I} \kappa \mathrm{B}$ kinase (IKK). NBD but not a control peptide decreased mortality and bowel injury in this model, supporting the hypothesis that bowel injury in NEC results from elevated NF- $\kappa$ B activity. Our findings therefore lead us to conclude that selective NF- $\kappa$ B inhibition represents a promising therapeutic strategy for NEC. (Pediatr Res 61: 716-721, 2007)
\end{abstract}

$\mathrm{N}^{\mathrm{B}}$ EC remains a major cause of morbidity and mortality in neonates (1). A neonatal rat model of NEC, reproducing typical risk factors of clinical NEC including formula feeding, hypoxia, and cold stress, has been used by recent investigators to gain insight into the pathogenesis of NEC $(2,3)$.

In animal models (4), as well as in clinical NEC (5), cytokine gene expression is up-regulated. This may result from the translocation of commensal bacteria and their products through an immature or compromised mucosal barrier, triggering an inflammatory cascade that leads to the release of cytokines and chemokines (6,7). Alternatively, bacteria can initiate the pro-inflammatory response by activating TLR4 on the surface of stressed epithelium, leading to intestinal inflam-

Received August 31, 2006; accepted January 19, 2007.

Correspondence: Isabelle G. De Plaen, M.D., Department of Pediatrics/Neonatology, \#45, Children's Memorial Hospital, 2300 Children's Plaza, Chicago, IL 60614; e-mail: isabelledp@northwestern.edu

This work was supported by a KO8 grant from the National Institutes of Health (5KO8HD044558) and an Illinois Department of Public Aid grant.

DOI: $10.1203 /$ pdr.0b013e3180534219 mation and necrosis (8). It is possible that, in premature neonates, the inflammatory response is not properly downregulated, resulting in excessive cytokine production. This leads to neutrophil recruitment, activation, reactive oxygen species release, and intestinal damage (7). However, the mechanisms regulating the inflammatory response in the neonatal intestine remain poorly understood.

$\mathrm{NF}-\kappa \mathrm{B}$, a transcription factor that regulates the expression of many inflammatory genes including pro-inflammatory cytokines, chemokines, and leukocyte adhesion molecules $(9,10)$, consists of five subunits (p50, p65, p52, cRel, and RelB) $(9,10)$ that homo- or heterodimerize to form active $\mathrm{NF}-\kappa \mathrm{B}$. The dimers of $\mathrm{NF}-\kappa \mathrm{B}$ mostly found in intestinal tissues are p50-p50 and p50-p65 $(11,12)$. NF- $\kappa \mathrm{B}$ is constitutively present in the cytoplasm of most cells, binding to inhibitory proteins named $\mathrm{I} \kappa \mathrm{B}$. Following stimulation, I $\kappa \mathrm{B}$ proteins are phosphorylated by an upstream IKK complex (9). This complex consists of two catalytic subunits, IKK $\alpha$ and IKK $\beta$, and a regulatory component, NEMO (13). Phosphorylation of $\mathrm{I} \kappa \mathrm{B}$ by the IKK complex leads to its ubiquitination and subsequent degradation by the $26 \mathrm{~S}$ proteasome, leaving $\mathrm{NF}-\kappa \mathrm{B}$ free to translocate to the nucleus and to regulate gene expression $(9,13)$.

$\mathrm{NF}-\kappa \mathrm{B}$ is aberrantly up-regulated in many chronic inflammatory diseases, including inflammatory bowel disease, and inhibition of $\mathrm{NF}-\kappa \mathrm{B}$ activation has been shown to decrease bowel injury (14). We previously demonstrated that $\mathrm{NF}-\kappa \mathrm{B}$ is constitutively present at low levels in adult rat intestine, and is activated in acute bowel injury induced by PAF, a potent endogenous phospholipid mediator thought to play a role in NEC pathogenesis (1). Nonetheless, the regulation of NF- $\kappa \mathrm{B}$ in the neonatal intestine and its role in NEC remain unknown. We hypothesize that a persistent and exaggerated NF- $\kappa \mathrm{B}$ activation in neonatal animals plays an important role in the development of NEC.

\footnotetext{
Abbreviations: EMSA, electrophoretic mobility shift assay; $\mathbf{I} \boldsymbol{\kappa B}$, inhibitor protein $\kappa \mathrm{B}$; IKK, I $\kappa \mathrm{B}$ kinase; iNOS, inducible nitric oxide synthase; LPS, lipopolysaccharide; NBD, NEMO-binding domain; NEC, necrotizing enterocolitis; NEMO, NF- $\kappa$ B essential modulator; NF- $\mathbf{k B}$, nuclear factor- $\kappa \mathrm{B}$; PAF, platelet-activating factor
} 
The goal of this study was therefore to investigate 1) the developmental regulation of NF- $\kappa \mathrm{B}$ activation and inhibitory proteins $\mathrm{I} \kappa \mathrm{B}$ in the neonatal rat intestine; 2) the change of $\mathrm{NF}-\kappa \mathrm{B}$ activity in experimental neonatal NEC, and 3) the effects of selective NF- $\kappa \mathrm{B}$ inhibition on NEC incidence in this model.

\section{METHODS}

Animal experiments. The study was approved by the Children's Memorial Research Center institutional animal care and use committee.

To study the perinatal activation of NF- $\kappa \mathrm{B}$ and iNOS gene expression, rat fetuses were delivered via abdominal incision of time-pregnant SpragueDawley rats (Harlan, Indianapolis, IN) at E18, E19, E20 or allowed to deliver naturally and left with the dams for different time periods. Their small intestines were removed, snap frozen in liquid nitrogen, and kept at $-80^{\circ} \mathrm{C}$ until nuclear protein or RNA extraction.

To study the regulation of NF- $\kappa \mathrm{B}$ in the NEC model, NEC was induced using the following protocol as previously described (3):

Time-pregnant Sprague-Dawley rats were delivered by an abdominal incision on d 21 of gestation following anesthesia-euthanasia in a $\mathrm{CO}_{2}$ chamber for $60 \mathrm{~s}$ followed immediately by cardiotomy. Neonatal pups were dried and placed in a humidified $\left(37^{\circ} \mathrm{C}\right)$ neonatal incubator (Air-Shield Vickers Medical, Hatboro, PA). Once recovered (about $1 \mathrm{~h}$ ), the pups were gavaged with $7 \times 10^{7}$ colony forming unit (CFU) of a standardized bacterial mixture diluted in $50 \mu \mathrm{L}$ of NS. Neonatal rats were fed Esbilac formula (33 $\mathrm{g}$ of powder diluted in $100 \mathrm{~mL}$ of water) by orogastric gavage using a $1.9 \mathrm{~F}$ silastic catheter. Gavage feedings were initiated with a volume of $0.1 \mathrm{~mL}$ every $3 \mathrm{~h}$. The volume was then increased by $0.05 \mathrm{~mL}$ every $12 \mathrm{~h}$. Pups were exposed to a brief episode of asphyxia $\left(60 \mathrm{~s}\right.$ in $100 \% \mathrm{~N}_{2}$ ) followed by cold stress $\left(4^{\circ} \mathrm{C}\right.$ for $\left.10 \mathrm{~min}\right)$, once on the day of birth and then twice daily. The standardized commensal bacterial mixture used in the NEC model was prepared as follows: the cecum content of three healthy adult rats was mixed 1:1 with regular growth media, vortexed, and cultured overnight at $37^{\circ} \mathrm{C}$. The bacterial suspension was mixed 1:1 with $50 \%$ glycerol-bacterial culture medium and multiple aliquots frozen at $-80^{\circ} \mathrm{C}$. The day before each experiment, a bacterial aliquot was thawed, cultured for $16 \mathrm{~h}$ at $37^{\circ} \mathrm{C}$ in culture medium, then diluted to the appropriate concentration. In a set of preliminary experiments, we have found that adding commensal bacteria to the protocol significantly increased the frequency and severity of NEC. The number of rats with histologic NEC score grade $0,1,2$, and 3 was 12, 2, 1, and 3, respectively, in the group without bacteria $(n=18)$, and $4,3,5$, and 3, respectively, in the group with bacterial inoculation $(n=15)$.

To evaluate the effect of NF- $\kappa \mathrm{B}$ inhibition on NEC, three litters were randomized into two groups around $3 \mathrm{~h}$ of life. Seven pups were excluded because of cyanosis (4) or very low birth weight $(<4 \mathrm{~g})$ (3). Healthy appearing pups in each litter were weighed and grouped so each group would be constituted of pups of similar weight and genetic background. Group 1 $(n=14)$ was treated with NBD $(20 \mathrm{mg} / \mathrm{kg}$, i.p. $)$ and group $2(n=15)$ with control peptide $(20 \mathrm{mg} / \mathrm{kg}$, i.p.) $1 \mathrm{~h}$ before the asphyxia/cold stress on $\mathrm{d} 0$ and d 1. Animals were observed closely and euthanized by decapitation when showing signs of distress (severe abdominal distension, respiratory distress, lethargy) or at $72 \mathrm{~h}$. Their small intestines were collected and fixed in buffered formalin for histologic examination. While the daytime technician could not be blinded for practical reasons, the night technician was kept unaware of the group identity.

Preparation of nuclear extracts. Frozen small intestines were ground into powder with a mortar in liquid nitrogen and nuclear extracts obtained following a standard protocol (11). For fetal tissues, two (E20) to three (E18-19) specimens were processed together to obtain sufficient amounts of nuclear extracts. Samples were stored in liquid nitrogen after determination of their protein concentration by the Bradford's method (15).

Determination of $N F-\kappa B-D N A$ binding activity by EMSA. Equal amounts of nuclear extract $(5 \mu \mathrm{g} / 10 \mu \mathrm{L})$ were used for EMSA and supershift experiment as previously published (11). The gel was dried and analyzed with a Storm 860 phosphorimaging system (Molecular Dynamics, Sunnyvale, CA). The intensity of the NF- $\kappa \mathrm{B}$ complex was quantified by densitometry, using ImageQuant software.

Preparation of intestinal whole cell extracts and Western blot analysis. Small intestinal tissue lysates were prepared by homogenization on ice for 1 min in ice-cold lysis buffer $(2.0 \mathrm{mM}$ Tris-Cl, $\mathrm{pH} 7.6,30 \mathrm{mM} \mathrm{NaCl}, 1 \mathrm{mM}$ EDTA, $0.2 \mathrm{mM}$ benzamidine, $1 \mathrm{mM}$ DTT, $1 \mathrm{mM}$ PMSF, $10 \mu \mathrm{g} / \mathrm{mL}$ leupeptin, $10 \mu \mathrm{g} / \mathrm{mL}$ aprotinin, $10 \mu \mathrm{g} / \mathrm{mL}$ pepstatin, $10 \mu \mathrm{g} / \mathrm{mL}$ chymotrypsin and $1 \%$ Nonidet P-40). Samples were centrifuged at 3,000 for $10 \mathrm{~min}$ at $4^{\circ} \mathrm{C}$ to remove tissue debris. The protein concentration of the tissue lysates was determined by the Bradford's method (15), and samples frozen at $-80^{\circ} \mathrm{C}$. Western blot for $\mathrm{I} \kappa \mathrm{B} \alpha, \mathrm{I} \kappa \mathrm{B} \beta$, and $\beta$-Actin was carried out as previously published and densitometry analysis was performed using the Openlab software (16).

iNOS mRNA analysis. mRNA was analyzed by RT-PCR as previously described (17). The primers used were as follows: rat iNOS primer 1: 5' ATG GCT TGC CCT TGG AAG TTT CTC 3', primer 2: 5' CTC CAG GCC ATC TTG GTG GCA AAG-3', rat GAPDH primer 1: $5^{\prime}$-ATT CTA CCC ACG GCA AGT TCA ATG G-3', primer 2: 5'-AGG GGC GGA GAT GAT GAC CC-3'.

Histologic analysis. Intestinal specimens were embedded in paraffin, sectioned, and stained with hematoxylin-eosin. Microscopic injury was graded by a blinded pathology study as follows: 0: intact villi; 1 : superficial epithelial cell sloughing; 2: mid-villous necrosis; 3 : complete villous necrosis; 4: transmural necrosis.

Statistical analysis. Two-sided $t$ test was used for the comparison of two single groups (densitometric analysis). To evaluate the differences in the incidence and severity of NEC, and in $72 \mathrm{~h}$-survival between the two groups, results were compared using $\chi^{2}$ analysis.

\section{RESULTS}

$N F-\kappa B$ is activated in the intestine after birth but its activation declines within $24 \boldsymbol{h}$ in dam-fed pups. We previously found that NF- $\kappa \mathrm{B}$ is constitutively active at low level in the intestine of adult rats (11). In this study, we show that a very low level of constitutive activation of NF- $\kappa \mathrm{B}$ becomes detectable in intestinal tissues at $20 \mathrm{~d}$ of gestation (normal gestation $21.5 \mathrm{~d}$ ) (Fig. 1A). In comparison, we did not find any constitutive activation of NF- $\kappa \mathrm{B}$ in the lung before or after birth (results not shown). Immediately after birth, NF- $\kappa \mathrm{B}$ is significantly activated in intestinal tissues (Fig. 1A). The complex contains mostly p50 subunits and a small amount of p65 (Fig. 1A). In control, dam-fed pups, NF- $\kappa \mathrm{B}$ activation is down-regulated within a day after birth in the small intestine (Fig. 1A and Fig. 3, $A$ and $B$ ). Prenatally, the level of intestinal inhibitory protein $\mathrm{I} \kappa \mathrm{B} \alpha$ and $\beta$ did not change significantly
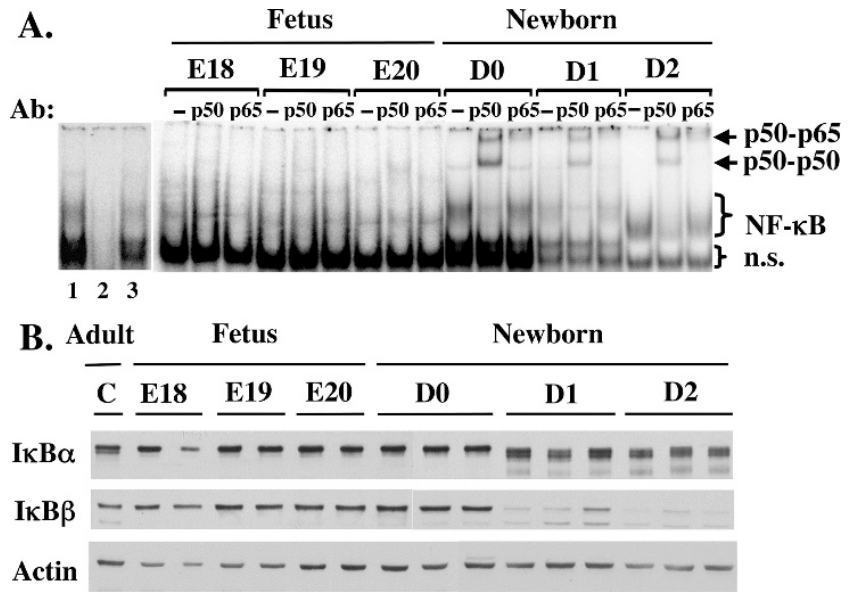

Figure 1. Intestinal NF- $\kappa$ B is activated at birth then down-regulated $24 \mathrm{~h}$ after birth. Small intestines of fetal rats delivered at different gestational ages (E18 to E20) and of neonatal pups (d 0, 1, and 2) were obtained. Nuclear extracts were prepared and NF- $\kappa$ B activity was assessed by EMSA of equal protein amounts of nuclear extracts $(A)$. Supershift experiments with antibodies $(A b)$ against p50 and p65, the two subunits found in the intestine, were performed (similar results were obtained in three independent experiments). n.s., Nonspecific complex with the NF- $\kappa \mathrm{B}$ probe that is not supershifted by anti-NF- $\kappa$ B subunit antibodies. On the left (lanes 1-3), a competitive experiment is shown where the D0 sample (lane 1) is incubated with an excess $(100 \times$-fold) of unlabeled NF- $\kappa \mathrm{B}$ probe (lane 2$)$ or an excess of an unrelated (AP-1) probe (lane 3). In $B$, the levels of $\mathrm{I} \kappa \mathrm{B} \alpha$ and $\beta$ were assessed by Western blot. 


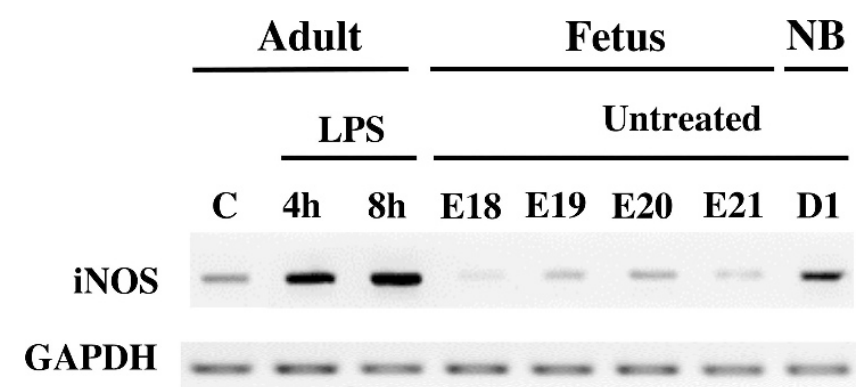

Figure 2. iNOS gene expression is up-regulated after birth and correlates temporally with the activation of NF- $\kappa \mathrm{B}$ activation in small intestinal tissues. The small intestine of fetal and neonatal rats of different ages was removed, total RNA (mRNA) was purified, and semi-quantitative RT-PCR for iNOS and GAPDH was performed. Samples from adult rat treated or not with LPS $7 \mathrm{mg} / \mathrm{kg}$ for 4 and $8 \mathrm{~h}$ is shown in comparison. $N B$, newborn. A typical PCR gel is shown.

with maturation (Fig. 1B). Just after birth (d 0$), \mathrm{I} \kappa \mathrm{B} \alpha$ and $\beta$ remained unchanged. In 1-d and 2-d dam-fed neonatal rats, the $\mathrm{I} \kappa \mathrm{B} \alpha$ complex intensity decreased to $93 \%$ and $87 \%$ of $\mathrm{d} 0$ value, respectively, and included a second band of faster migration. At $\mathrm{d} 1$ and $\mathrm{d} 2$, the level of $\mathrm{I} \kappa \mathrm{B} \beta$ was significantly decreased (60\% and $46 \%$ of d 0 value, respectively) (Fig. $1 B$ ).

Expression of iNOS, a downstream target of $N F-\kappa B$ correlates temporally after birth with elevated $N F-\kappa B$ activity. In the fetal rat ileum, iNOS was minimally expressed (Fig. 2). However, following birth, its expression was strongly upregulated (Fig. 2), similar to that in adult rats challenged with $7 \mathrm{mg} / \mathrm{kg}$ LPS intraperitoneally, a well-characterized activator of iNOS gene expression (16).

$N F-\kappa B$ is persistently activated in a neonatal rat model of $N E C$. In neonatal rats subjected to the stress of formula feedings, hypoxia and cold exposure (NEC model), NF- $\kappa \mathrm{B}$ activation remains high at $\mathrm{d} 1$ and 2 (Fig. 3). The levels reached 3.6-fold $( \pm 0.2)$ (mean \pm SEM) of dam-fed control values on $d 1$ and 2.7-fold $( \pm 0.1)$ on d 2 (Fig. 3C) $(p<0.001)$. Although the NF- $\kappa \mathrm{B}$ complexes observed on $\mathrm{d} 1$ and 2 were mostly supershifted with anti-p50 antibodies, they also contained p65.

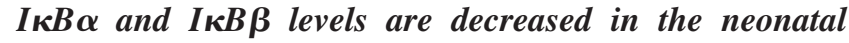
intestine in NEC at D2. While we did not find any differences in the level of $\mathrm{I} \kappa \mathrm{B} \alpha$ and $\mathrm{I} \kappa \mathrm{B} \beta$ at $\mathrm{D} 1$, their levels were decreased in the ileum of stressed animals at $\mathrm{d} 2$ compared with those of controlled dam-fed newborns (93\% of DF value for $\mathrm{I} \kappa \mathrm{B} \alpha$ and $83 \%$ for $\mathrm{I} \kappa \mathrm{B} \beta$ ) (Fig. 4). Although equivalent

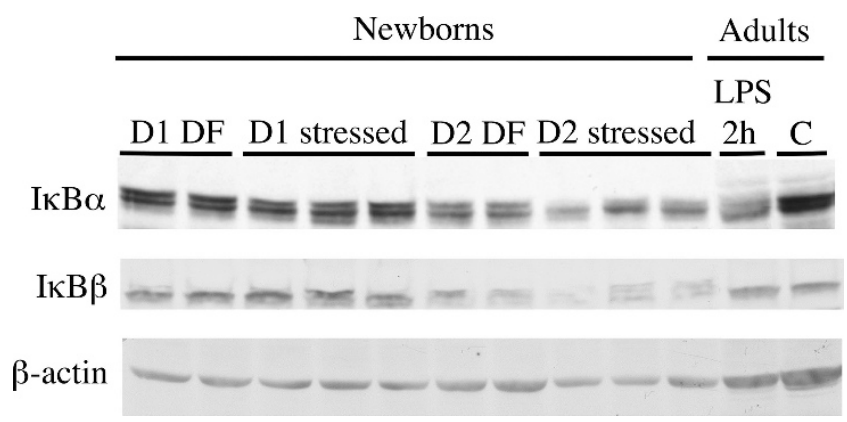

Figure 4. Western blot analysis of $\mathrm{I} \kappa \mathrm{B} \alpha$ and $\mathrm{I} \kappa \mathrm{B} \beta$ proteins in the rat ileum. Small intestinal tissue lysates from stressed pups or dam-fed controls $(D F)$ were obtained at $\mathrm{d} 1$ and 2, and (for comparison) from adult rats untreated $(C)$ or treated with LPS $7 \mathrm{mg} / \mathrm{kg}$ intraperitoneally for $2 \mathrm{~h}$. Equal amounts of protein from each sample were subjected to SDS-PAGE and the gels to immunoblot analysis with anti- $\mathrm{I} \kappa \mathrm{B} \alpha, \mathrm{I} \kappa \mathrm{B} \beta$, and $\beta$-actin antibodies.

amounts of protein were loaded, $\beta$-actin protein levels were consistently higher in adult tissues compared with those of newborns, suggesting that $\beta$-actin is developmentally regulated in the intestine. These differences were accounted for in the interpretation of $\mathrm{I} \kappa \mathrm{B}$ protein levels.

NBD peptide protects against bowel injury and decreases mortality in a neonatal rat model of NEC. Treatment with the NBD, but not a mutated control peptide, significantly decreased intestinal NF- $\kappa \mathrm{B}$ activation in stressed neonatal animals (Fig. 5). Furthermore, animals that received the NBD peptide exhibited improved survival compared with controls (10/14 versus $5 / 15)\left(\chi^{2}=4.2 ; p<0.05\right)$ (Fig. $\left.6 A\right)$.

Animals pretreated with the NBD peptide had a decreased incidence of NEC (any grade) compared with animals treated with control peptide $(2 / 14$ versus $9 / 15)\left(\chi^{2}=6.42 ; p<0.025\right)$ (Figs. $6 B$ and 7). This corresponds to a mean ( \pm SEM) histologic score of $1.3( \pm 0.34)$ [95\% confidence interval (CI), $0.61-1.99$ ] for the control group and a mean ( \pm SEM) histologic score of $0.14( \pm 0.1)(95 \% \mathrm{CI}, 0.07-0.35)$ in the NBD group $(p<0.01)$. Also, none of the animals in the NBD group had severe NEC (defined as having a score of 2 or higher) compared with 5 severe NEC in the control peptide group $(5 / 15$, versus $0 / 14)\left(\chi^{2}=5.64 ; p<0.025\right)$ (Figs. $6 B$ and 7$)$.

\section{DISCUSSION}

The pathogenic mechanism leading to NEC remains poorly understood. We hypothesized that, in the premature infant, a
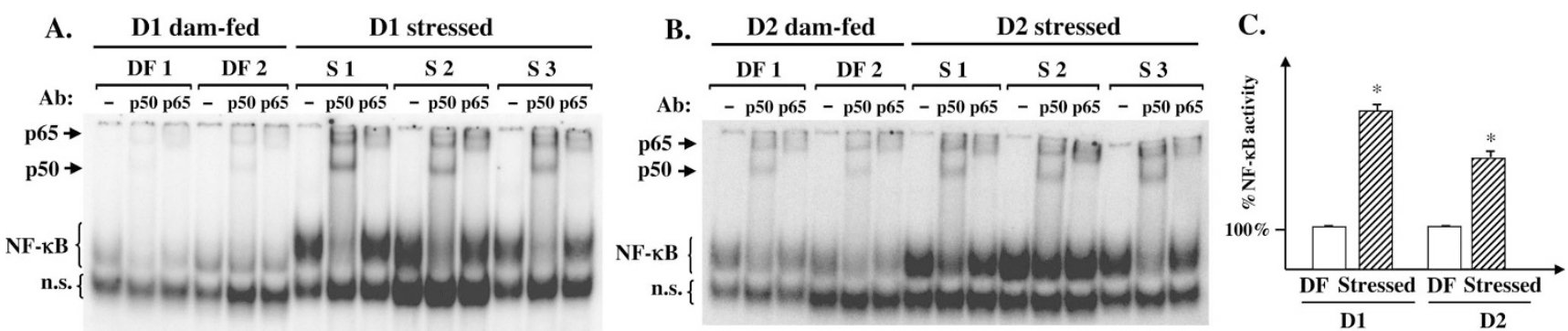

Figure 3. NF- $\kappa \mathrm{B}$ is activated in a neonatal rat model of NEC. The small intestines of newborn rats submitted to formula feedings, hypoxia and cold stress $(S)$ and of dam-fed control $(D F)$ pups were obtained at $\mathrm{d} 1(A$ and $C$ ) and at $\mathrm{d} 2(B$ and $C)$ and nuclear extracts prepared (six to eight samples per group). The NF- $\kappa \mathrm{B}$ activity was assessed by EMSA and supershift experiments with antibodies $(A b)$ against p50 and p65 were performed. NF- $\kappa \mathrm{B}-\mathrm{DNA}$ binding activity was quantified by densitometry $(C)$. A mean value was calculated for dam-fed control at d1 and results were expressed as a percentage of the dam-fed controls $\pm \operatorname{SEM}(* p<0.001)$. 


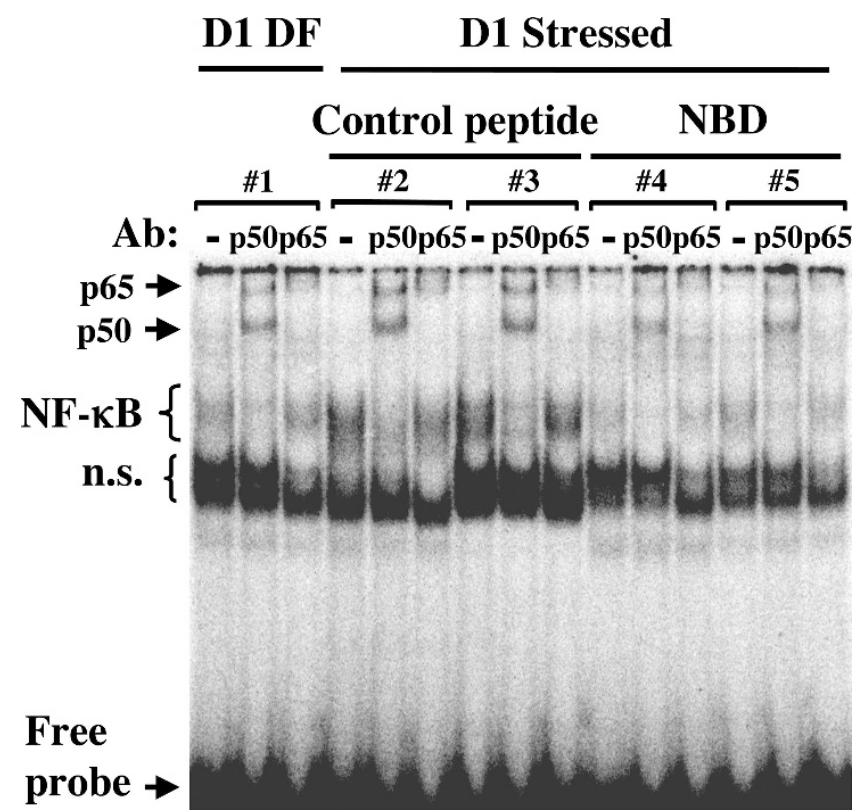

Figure 5. The NBD peptide inhibits NF- $\kappa \mathrm{B}$ activation in vivo in the intestine. Small intestinal tissues of stressed pups (\#1-5) treated with the NBD or control peptide were obtained at d 1 and were processed to obtain nuclear extracts. NF- $\kappa \mathrm{B}$ activity was examined by EMSA and supershift experiments performed with anti-p50 and anti-p65 antibodies. A typical gel is shown here with the sample of a dam-fed control for comparison. Similar results were obtained in three independent experiments.

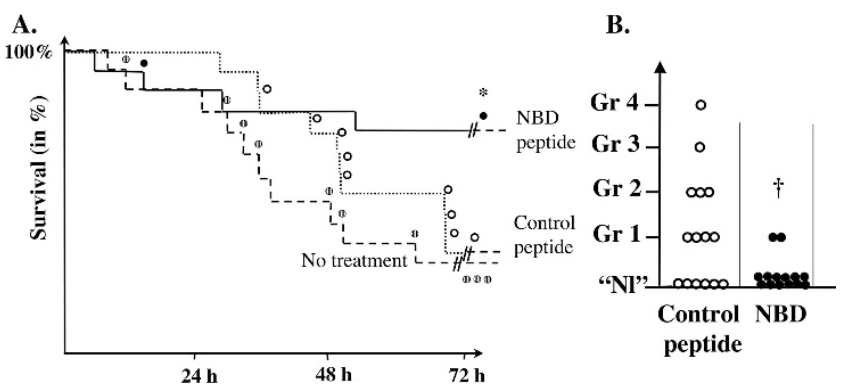

Figure 6. Effect of the NBD peptide on intestinal injury score and neonatal survival in a neonatal rat model of NEC. Neonatal rats were either untreated or treated with the NBD peptide $(20 \mathrm{mg} / \mathrm{kg}$, i.p.) $(n=14)$ or control peptide $(20 \mathrm{mg} / \mathrm{kg}$, i.p.) $(n=15) 1 \mathrm{~h}$ before the first stress at D0 and D1. Intestines were fixed in formalin immediately at time of death and sections were examined by a pathologist blinded to the groups. The survival curve $(A)$ and the injury score $(B)$ is presented here $(* p<0.05, \dagger p<0.025$; grade 0 : intact villi; 1: superficial epithelial cell sloughing; 2: mid-villous necrosis; 3 : complete villous necrosis; 4: transmural necrosis). In $A, \bigcirc$ : NEC and a survival curve of pups submitted to the NEC protocol without treatment is shown for comparison.

persistent and excessive activation of the transcription factor $\mathrm{NF}-\kappa \mathrm{B}$ could lead to persistent intestinal inflammation, injury, and NEC. In this study, we found that 1$) \mathrm{NF}-\kappa \mathrm{B}$ was persistently activated in stressed neonatal animals, 2) I $\kappa \mathrm{B} \alpha$ was decreased compared with dam-fed or adult animals at $\mathrm{d} 2$, and 3 ) the NBD peptide, a potent and selective IKK/NF- $\kappa$ B inhibitor, reduced intestinal NF- $\kappa \mathrm{B}$ activation and the incidence of NEC and death in neonatal rats. These findings therefore support the important role of persistent NF- $\kappa \mathrm{B}$ activation in the pathogenesis of NEC.

A common feature of NEC is the production and release of inflammatory mediators, including PAF (18) and NF- $\kappa \mathrm{B}$ tar-
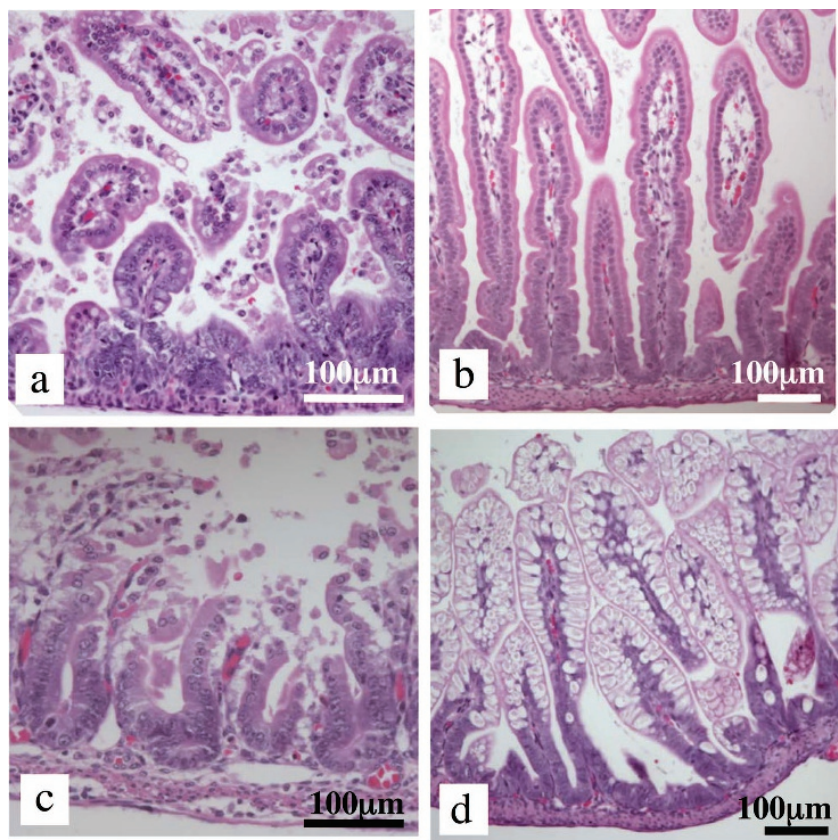

\section{Control peptide:}

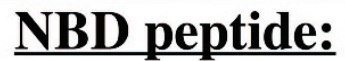

Figure 7. Small intestinal microscopic changes following the NEC protocol. Various degrees of experimental necrotizing enterocolitis were observed in the control animals ( $a$ and $c$ ), whereas minimal injury was found in the animals treated with NBD before the NEC protocol $(b$ and $d)$.

get gene products such as TNF $(5,6)$ and the chemokine CXCL2, both of which are pivotal in mediating experimental bowel necrosis $(17,19)$.

$\mathrm{NF}-\kappa \mathrm{B}$ is activated in many disease processes, including septic shock (20) and ulcerative colitis (21), and we previously demonstrated that it is activated in a model of acute bowel injury induced by PAF (11). However, very little is known about the activation of NF- $\kappa \mathrm{B}$ during the perinatal/neonatal period and its role in the pathogenesis of NEC. In this study, we found a very low level of constitutive NF- $\kappa$ B activation in intestinal tissues during late gestation, but strong activation immediately after birth. This activation correlated temporally with the expression of iNOS, a well-documented NF- $\kappa$ B target gene (22). In normal, dam-fed animals, this activation is down-regulated within $24 \mathrm{~h}$. In contrast however, we find that $\mathrm{NF}-\kappa \mathrm{B}$ remains persistently active in animals subjected to the induction of NEC. Transient activation of NF- $\kappa \mathrm{B}$ at birth might be due to the exposure to bacterial products and to oxidative stress-inducing signals associated with delivery. Although transient activation of NF- $\kappa \mathrm{B}$ at the time of birth might be protective and important for mounting a limited pro-inflammatory response that allows proper control of bacterial colonization, a persistent and exaggerated NF- $\kappa \mathrm{B}$ activation might be detrimental, causing excessive cytokine release and intestinal injury.

Several clinical interventions have been shown to decrease the incidence of NEC including prenatal steroids (23), breast milk (24), and probiotics (25), all of which have been shown to down-regulate NF- $\kappa$ B. Dexamethasone suppresses NF- $\kappa$ B activation by inducing the NF- $\kappa \mathrm{B}$ inhibitor $\mathrm{I} \kappa \mathrm{B}(26)$ and by direct protein-protein interactions that prevent NF- $\kappa \mathrm{B}$ from 
inducing transcription in a promoter site-specific fashion (27). Breast milk might contribute to decreased intestinal inflammation, as human breast milk has been shown to suppress the activation of the IL- 8 gene promoter induced by IL- $1 \beta$ through NF- $\kappa$ B in intestinal epithelial cells (28). In these cells, human breast milk induces the production of $\mathrm{I} \kappa \mathrm{B} \alpha$ (28). Probiotics have also shown promise as a prophylactic intervention to prevent NEC (25), and part of their effects may be $\mathrm{NF}-\kappa \mathrm{B}$ inhibition in colonic epithelial cells through proteasome inhibition (29).

Studies suggest that NF- $\kappa \mathrm{B}$ might be developmentally regulated in various organs or cell-types. For example, IL-8 production and NF- $\kappa \mathrm{B}$ activation in response to TNF is higher in neonatal polymorphonuclear leukocytes than adult cells (30). Of interest to neonatal intestinal disease, the expression of $\mathrm{I} \kappa \mathrm{B} \alpha$ was found to be lower in immature versus mature enterocytes (31) with concomitant increased production of IL- 8 in response to LPS and IL- $1 \beta$ in these fetal epithelial cell explants (32).

We did not find any significant prenatal changes in constitutive $\mathrm{I} \kappa \mathrm{B} \alpha$ and $\mathrm{I} \kappa \mathrm{B} \beta$ with maturation. Although NF- $\kappa \mathrm{B}$ is strongly activated immediately after birth, the $\mathrm{I} \kappa \mathrm{B} \alpha$ and $\mathrm{I} \kappa \mathrm{B} \beta$ levels remain unchanged. This lack of correlation was also observed in IEC cells (16): A drop in the $\mathrm{I} \kappa \mathrm{B} \alpha$ level could be detected only when cells were also co-incubated with cycloheximide, which inhibited $\mathrm{I} \kappa \mathrm{B} \alpha$ resynthesis. This occurs because $\mathrm{I} \kappa \mathrm{B} \alpha$ is a downstream gene target of NF- $\kappa \mathrm{B}$ and is rapidly resynthesized upon NF- $\kappa \mathrm{B}$ activation (33). We found that, in 1-d and 2-d dam-fed neonatal rats, whereas $\mathrm{I} \kappa \mathrm{B} \alpha$ was only slightly decreased, the level of I $\kappa \mathrm{B} \beta$ dropped significantly. The level of $\mathrm{I} \kappa \mathrm{B} \alpha$ and of $\mathrm{I} \kappa \mathrm{B} \beta$ further decreased in stressed animals compared with dam-fed controls at $\mathrm{d} 2$ of life.

Whereas NF- $\kappa$ B activation has been demonstrated in several experimental models of pro-inflammatory disease, its role in neonatal NEC has not been determined. We studied the importance of NF- $\kappa \mathrm{B}$ activation in NEC using a specific $\mathrm{NF}-\kappa \mathrm{B}$ inhibitory peptide that contains the C-terminal NBD sequence from IKK $\alpha$ and $\operatorname{IKK} \beta$ (a hexapeptide sequence required for interaction of the IKK with NEMO) coupled with the cell permeable antennapedia domain (34). By binding to NEMO, it blocks its association with the IKK complex and inhibits NF- $\kappa \mathrm{B}$ activation without interrupting the constitutive activity of NF- $\kappa \mathrm{B}$ (34). The NBD peptide has been shown to inhibit cytokine-induced NF- $\kappa \mathrm{B}$ activation and NF- $\kappa \mathrm{B}-$ dependent gene expression in Hela cells (34), and we previously demonstrated that it blocks LPS-induced MIP-2/CXCL2 gene expression in enterocytes (35). Importantly, the NBD peptide effectively ameliorates inflammation in vivo in models such as ear edema (34), acute peritonitis (induced by intraperitoneal injection of zymosan), and experimental acute pancreatitis (36).

In this study, we found that the NBD peptide inhibited intestinal NF- $\kappa$ B activation, improved neonatal survival, and decreased the incidence of histologically confirmed bowel injury in neonatal NEC. This observation therefore strongly suggests that bowel injury in NEC may result from a dysregulation of IKK activity. Furthermore, although our data are derived from a limited sample size and must be viewed as preliminary, they provide extremely compelling evidence supporting further in-depth in vivo investigations of the NBD peptide in animal models of NEC.

In summary, our study demonstrates that NF- $\kappa \mathrm{B}$ is persistently activated in a neonatal model of NEC and that dysregulated IKK activity mediates these effects. Our data suggest that, although limited NF- $\kappa$ B activation in specific cells of the intestine is likely to be protective, a prolonged activation of NF- $\kappa \mathrm{B}$ above a certain threshold might be detrimental. Further studies are required to better characterize the role of NF- $\kappa \mathrm{B}$ activation in NEC before we consider NF- $\kappa$ B inhibition as a therapeutic approach to NEC. However, our in vivo findings provide a compelling argument for aggressively pursuing $\mathrm{NF}-\kappa \mathrm{B}$ as therapeutic target.

\section{REFERENCES}

1. Hsueh W, Caplan MS, Qu XW, Tan XD, De Plaen IG, Gonzalez-Crussi F 2003 Neonatal necrotizing enterocolitis: clinical considerations and pathogenetic concepts. Pediatr Dev Pathol 6:6-23

2. Barlow B, Santulli TV, Heird WC, Pitt J, Blanc WA, Schullinger JN 1974 An experimental study of acute neonatal enterocolitis-the importance of breast milk. J Pediatr Surg 9:587-595

3. Caplan MS, Hedlund E, Adler L, Hsueh W 1994 Role of asphyxia and feeding in a neonatal rat model of necrotizing enterocolitis. Pediatr Pathol 14:1017-1028

4. Chung DH, Ethridge RT, Kim S, Owens-Stovall S, Hernandez A, Kelly DR, Evers BM 2001 Molecular mechanisms contributing to necrotizing enterocolitis. Ann Surg 233:835-842

5. Viscardi RM, Lyon NH, Sun CC, Hebel JR, Hasday JD 1997 Inflammatory cytokine mRNAs in surgical specimens of necrotizing enterocolitis and normal newborn intestine. Pediatr Pathol Lab Med 17:547-559

6. Harris MC, Costarino AT Jr, Sullivan JS, Dulkerian S, McCawley L, Corcoran L, Butler S, Kilpatrick L 1994 Cytokine elevations in critically ill infants with sepsis and necrotizing enterocolitis. J Pediatr 124:105-111

7. Markel TA, Crisostomo PR, Wairiuko GM, Pitcher J, Tsai BM, Meldrum DR 2006 Cytokines in necrotizing enterocolitis. Shock 25:329-337

8. Jilling T, Simon D, Lu J, Meng FJ, Li D, Schy R, Thomson RB, Soliman A, Arditi M, Caplan MS 2006 The roles of bacteria and TLR4 in rat and murine models of necrotizing enterocolitis. J Immunol 177:3273-3282

9. Hayden MS, Ghosh S 2004 Signaling to NF-kappaB. Genes Dev 18:2195-2224

10. Li Q, Verma IM 2002 NF-kappaB regulation in the immune system. Nat Rev Immunol 2:725-734

11. De Plaen IG, Tan XD, Chang H, Qu XW, Liu QP, Hsueh W 1998 Intestinal NF-kappaB is activated, mainly as p50 homodimers, by platelet-activating factor. Biochim Biophys Acta 1392:185-192

12. De Plaen IG, Tan XD, Chang H, Wang L, Remick DG, Hsueh W 2000 Lipopolysaccharide activates nuclear factor kappaB in rat intestine: role of endogenous platelet-activating factor and tumour necrosis factor. Br J Pharmacol 129:307-314

13. DiDonato JA, Hayakawa M, Rothwarf DM, Zandi E, Karin M 1997 A cytokineresponsive IkappaB kinase that activates the transcription factor NF-kappaB. Nature 388:548-554

14. Murano M, Maemura K, Hirata I, Toshina K, Nishikawa T, Hamamoto N, Sasaki S, Saitoh O, Katsu K 2000 Therapeutic effect of intracolonically administered nuclear factor kappa B (p65) antisense oligonucleotide on mouse dextran sulphate sodium (DSS)-induced colitis. Clin Exp Immunol 120:51-58

15. Bradford MM 1976 A rapid and sensitive method for the quantitation of microgram quantities of protein utilizing the principle of protein-dye binding. Anal Biochem $72: 248-254$

16. De Plaen IG, Qu XW, Wang H, Tan XD, Wang L, Han XB, Rozenfeld RA, Hsueh W 2002 Endotoxin, but not platelet-activating factor, activates nuclear factorkappaB and increases IkappaBalpha and IkappaBbeta turnover in enterocytes. Immunology 106:577-583

17. Han XB, Liu X, Hsueh W, De Plaen IG 2004 Macrophage inflammatory protein-2 mediates the bowel injury induced by platelet-activating factor. Am J Physiol Gastrointest Liver Physiol 287:G1220-G1226

18. Rabinowitz SS, Dzakpasu P, Piecuch S, Leblanc P, Valencia G, Kornecki E 2001 Platelet-activating factor in infants at risk for necrotizing enterocolitis. J Pediatr 138:81-86

19. Halpern MD, Clark JA, Saunders TA, Doelle SM, Hosseini DM, Stagner AM, Dvorak B 2006 Reduction of experimental necrotizing enterocolitis with anti-TNFalpha. Am J Physiol Gastrointest Liver Physiol 290:G757-G764

20. Liu SF, Ye X, Malik AB 1997 In vivo inhibition of nuclear factor-kappa B activation prevents inducible nitric oxide synthase expression and systemic hypotension in a rat model of septic shock. J Immunol 159:3976-3983

21. Gan HT, Chen YQ, Ouyang Q 2005 Sulfasalazine inhibits activation of nuclear factor-kappaB in patients with ulcerative colitis. J Gastroenterol Hepatol 20:10161024 
22. Xie QW, Kashiwabara Y, Nathan C 1994 Role of transcription factor NF-kappa $\mathrm{B} / \mathrm{Rel}$ in induction of nitric oxide synthase. J Biol Chem 269:4705-4708

23. Bauer CR, Morrison JC, Poole WK, Korones SB, Boehm JJ, Rigatto H, Zachman RD 1984 A decreased incidence of necrotizing enterocolitis after prenatal glucocorticoid therapy. Pediatrics 73:682-688

24. Lucas A, Cole TJ 1990 Breast milk and neonatal necrotising enterocolitis. Lancet 336:1519-1523

25. Lin $\mathrm{HC}$, Su BH, Chen AC, Lin TW, Tsai CH, Yeh TF, Oh W 2005 Oral probiotics reduce the incidence and severity of necrotizing enterocolitis in very low birth weight infants. Pediatrics 115:1-4

26. Auphan N, DiDonato JA, Rosette C, Helmberg A, Karin M 1995 Immunosuppression by glucocorticoids: inhibition of NF-kappa B activity through induction of I kappa B synthesis. Science 270:286-290

27. Reichardt HM, Tuckermann JP, Gottlicher M, Vujic M, Weih F, Angel P, Herrlich P, Schutz G 2001 Repression of inflammatory responses in the absence of DNA binding by the glucocorticoid receptor. EMBO J 20:7168-7173

28. Minekawa R, Takeda T, Sakata M, Hayashi M, Isobe A, Yamamoto T, Tasaka K, Murata Y 2004 Human breast milk suppresses the transcriptional regulation of IL-1beta-induced NF-kappaB signaling in human intestinal cells. Am J Physiol Cell Physiol 287:C1404-C1411

29. Petrof EO, Kojima K, Ropeleski MJ, Musch MW, Tao Y, De Simone C, Chang EB 2004 Probiotics inhibit nuclear factor-kappaB and induce heat shock proteins in colonic epithelial cells through proteasome inhibition. Gastroenterology 127:1474-1487
30. Vancurova I, Bellani P, Davidson D 2001 Activation of nuclear factor-kappaB and its suppression by dexamethasone in polymorphonuclear leukocytes: newborn versus adult. Pediatr Res 49:257-262

31. Claud EC, Lu L, Anton PM, Savidge T, Walker WA, Cherayil BJ 2004 Developmentally regulated IkappaB expression in intestinal epithelium and susceptibility to flagellin-induced inflammation. Proc Natl Acad Sci U S A 101:7404-7408

32. Nanthakumar NN, Fusunyan RD, Sanderson I, Walker WA 2000 Inflammation in the developing human intestine: a possible pathophysiologic contribution to necrotizing enterocolitis. Proc Natl Acad Sci U S A 97:6043-6048

33. Arenzana-Seisdedos F, Thompson J, Rodriguez MS, Bachelerie F, Thomas D, Hay RT 1995 Inducible nuclear expression of newly synthesized I kappa B alpha negatively regulates DNA-binding and transcriptional activities of NF-kappa B. Mol Cell Biol 15:2689-2696

34. May MJ, D’Acquisto F, Madge LA, Glockner J, Pober JS, Ghosh S 2000 Selective inhibition of NF-kappaB activation by a peptide that blocks the interaction of NEMO with the IkappaB kinase complex. Science 289:1550-1554

35. De Plaen IG, Han XB, Liu X, Hsueh W, Ghosh S, May MJ 2006 Lipopolysaccharide induces CXCL2/macrophage inflammatory protein-2 gene expression in enterocytes via NF-kappaB activation: independence from endogenous TNF-alpha and plateletactivating factor. Immunology 118:153-163

36. Ethridge RT, Hashimoto K, Chung DH, Ehlers RA, Rajaraman S, Evers BM 2002 Selective inhibition of NF-kappaB attenuates the severity of cerulein-induced acute pancreatitis. J Am Coll Surg 195:497-505 